\title{
The end of what? Phenomenology vs. speculative realism
}

\author{
Zahavi, Dan
}

Published in:

International Journal of Philosophical Studies

DOI:

10.1080/09672559.2016.1175101

Publication date:

2016

Document version

Early version, also known as pre-print

Citation for published version (APA):

Zahavi, D. (2016). The end of what? Phenomenology vs. speculative realism. International Journal of Philosophical Studies, 24(3), 289-309. https://doi.org/10.1080/09672559.2016.1175101 
Published in International Journal of Philosophical Studies 24/3, 2016, 289-309. Please quote from published version.

Dan Zahavi

Center for Subjectivity Research, University of Copenhagen, Denmark

\section{The end of what? Phenomenology vs. speculative realism}

The question of how to understand and respond to naturalism has been of concern to phenomenology ever since its commencement. It figured centrally in Husserl's discussion of psychologism in Logische Untersuchungen, in his programmatic manifesto Philosophie als strenge Wissenschaft, in his last work Die Krisis der europäischen Wissenschaften und die transzendentale Phänomenologie, and in his 1919 lectures Natur und Geist, to mention just a few relevant texts. It was also at the forefront of Merleau-Ponty's first major work La structure du comportement. More recently, Francisco Varela's work on neurophenomenology has been decisive in rekindling interest in the issue and has led to an intense discussion of whether it is possible to naturalize phenomenology (Varela 1996). One important milestone in this debate was the landmark volume Naturalizing Phenomenology from 1999, where Varela and his three co-editors argued that it was crucial for the advancement of cognitive science that it adapted some of the methodological tools that were developed by Husserl and Merleau-Ponty (Petitot et al. 1999).

17 years later, the discussion continues. In a number of previous publications, I have argued that the answer to the question of whether a naturalized phenomenology is a desideratum or a category mistake very much depends on what one takes the question to be, and that it is urgent to be clear on what notion of phenomenology and what notion of nature and naturalization one has in mind (Zahavi 2004a, 2010a, 2013). One obvious challenge to any happy marriage obviously derives from the transcendental character of phenomenology. Contrary to some proposals, it is not naturalism's classical endorsement of some form of physicalism that constitutes the main obstacle to a reconciliation. It is not as if matters would improve if naturalism opted for some version of emergentism or property dualism. The real problem has to do with naturalism's commitment to metaphysical realism, and with its treatment of consciousness as a mere object in the world.

Much of the recent discussion of these issues has taken place in the border area between phenomenology, cognitive science and analytic philosophy of mind. Recently, however, a new discussion partner has appeared on the scene. One that very much wants to get non-human nature back on stage, whose relation to naturalism is complicated, and whose attitude towards phenomenology can only be described as deeply hostile. This new partner, called speculative realism, is heralded (by its proponents) as one of the most exciting and promising new currents in Continental philosophy.

\section{The end of phenomenology}


In a recent book entitled The End of Phenomenology, Sparrow offers an overview of speculative realism and highlights its relation to phenomenology. Sparrow's own explanation of his title is twofold. On the one hand, he argues that the rise of speculative realism brings phenomenology to a close. Why is that? Because speculative realism delivers what phenomenology always promised, but never provided: A wholehearted endorsement of realism (Sparrow 2014, xi). On the other hand, however, Sparrow also argues that phenomenology never really got started. It began and ended with Husserl. Since Husserl, according to Sparrow, was never able to settle on what phenomenology should become "it is not clear that it ever was anything at all" (Sparrow 2014, xi). In fact, the case could be "made that phenomenology never really existed" (Sparrow 2014, 204), since no proponent of phenomenology has ever been able to "adequately clarify its method, scope, and metaphysical commitments" (Sparrow 2014, xiii). That many self-declared phenomenologists have failed to realize this merely attests to the fact that they are a kind of living dead. Sparrow even goes so far as to suggest that phenomenology is a form of zombie philosophy, "extremely active, but at the same time lacking philosophical vitality and methodologically hollow" (Sparrow 2014, 187).

The harshness of Sparrow's rhetoric is reminiscent of the work by Tom Rockmore, who Sparrow often quotes as a source of authority. In his book Kant and Phenomenology, for instance, Rockmore maintains that Husserl never managed to make it clear precisely what he meant by phenomenology; that he was unable to clarify his basic account of the relationship between phenomenology and epistemology; that he repeatedly failed to address his own questions, and often just obscured the issues at stake. Thus, for Rockmore, Husserl's methodology, as well as most of his central concepts, including notions such as intuition, essence, representation, constitution, noesis, noema and phenomenological reduction, remain fundamentally obscure (Rockmore 2011, 116, 127, 131, etc.).

Sparrow's own interpretation is as tendentious as Rockmore's. ${ }^{1}$ To select just one example among many, consider Sparrow's claim that Merleau-Ponty in Phenomenology of perception "affirms that yes, phenomenology is impossible" (Sparrow 2014, 48). How does Sparrow reach such a conclusion? In his preface to Phenomenology of Perception, Merleau-Ponty characterizes phenomenology as a perpetual critical (self-)reflection. It should not take anything for granted, least of all itself. It is, to put it differently, a constant meditation (Merleau-Ponty 2012: 1xxxv). Merleau-Ponty's point is that phenomenology is always on the way, but Sparrow equates this anti-dogmatic attitude with the view that phenomenology can never get started. In addition, Sparrow also takes issue with Merleau-Ponty's famous assertion that "the most important lesson of the reduction is the impossibility of a complete reduction" (2012: 1xxvii), and interprets it as amounting to the claim that the reduction is a methodological step that cannot be undertaken (Sparrow 2014, 48). If the reduction is crucial to phenomenology - as some would insist -, it would again show that phenomenology is impossible. As a closer engagement with the text will show, however, this is not what Merleau-Ponty is saying. The reduction is a form of reflective move (see Zahavi 2015), and Merleau-Ponty's point is rather that we as finite creatures are incapable of effectuating an absolute reflection that once and for all would allow us to cut our ties to our world-immersed life and permit us to survey it from a view from

\footnotetext{
${ }^{1}$ One of Rockmore's claims is that one should reject the often repeated "myth" that Husserl is the inventor of phenomenology and instead credit Kant as the first true phenomenologist (Rockmore 2011, 8). In fact, Rockmore even questions whether Husserl, Heidegger and Merleau-Ponty deserves being classified as phenomenologists (Rockmore 2011, 210). For a critical review of Rockmore's book, cf. Zahavi 2012a.
} 
nowhere. Even the most radical reflection depends upon and is linked to an unreflected life that, as Merleau-Ponty puts it, remains its initial, constant, and final situation (Merleau-Ponty 2012, lxxviii). To say that the reduction cannot be completed is not to say that it cannot be carried out. After all, it is only by distancing ourselves, if ever so slightly, from our world-immersed life that we can describe it. It is only by slacking them slightly, that we can make the intentional threads that connect us to the world visible (Merleau-Ponty 2012: 1xxvii). But this procedure is something that has to be performed repeatedly, rather than completed once and for all. To that extent, Merleau-Ponty's remarks about the unfinished character of phenomenology and about the incomplete reduction are two ways of making the same point. None of this entails that Merleau-Ponty should affirm that phenomenology or the reduction is impossible, which, of course, is also why he can insist that Heidegger's analysis of beingin-the-world presupposes the reduction (Merleau-Ponty 2012: lxxviii).

Sparrow's misinterpretation of Merleau-Ponty aside, his main criticism is obviously directed at what he takes to be the ambiguities of the phenomenological method. Husserl's inability to come up with a definite account of his own method, the fact that he never bequeathed us with something like Descartes's Regulae ad directionem ingenii is, according to Sparrow, a fatal vice and weakness, since it entails that it is entirely unclear how phenomenology is supposed to be carried out (Sparrow 2014, 5-6). That subsequent phenomenologists have rebelled against Husserl's methodological requirements only makes matters even worse. There is for Sparrow no consensus, and no criteria, that will allow us to differentiate what is phenomenological, from what is not (Sparrow 2014, 3-4, 10). ${ }^{2}$

At this point, Sparrow starts to vacillate between three different positions. The first is the one just mentioned, namely that phenomenology has no method and stable identity. The second is that phenomenology is indeed unified by its commitment to a transcendental method: As he writes, "for a philosophical description, study, or conclusion to count as phenomenological - that is, to mark it as something other than everyday description, empirical study, or speculative metaphysics - that

\footnotetext{
${ }^{2}$ On previous occasions, I have defended the coherency of Husserl's transcendental phenomenology (cf. Zahavi 1996, 2003, 2010b), just as I have also argued that there are a number of overarching concerns and common themes that unifies the major figures of classical phenomenology (Zahavi 2007, 2008). I will not rehearse these arguments here. When discussing the question of whether a philosophical tradition is sufficiently unified to count as a tradition, it might, however, be unwise to adopt such rigid criteria that one ultimately risks proving just about any philosophical tradition out of existence. Were one to accept Sparrow's approach, it is hard to see how critical theory, hermeneutics, pragmatism or analytic philosophy could survive. Indeed, if consensus concerning a fixed set of methodological tools is a necessary condition for the existence of a research program, hardly any would exist. A somewhat similar remark holds true in the case of individual figures. It is hard to point to any influential thinker in the history of philosophy whose work has not given rise to scholarly disagreements and conflicting interpretations. A purist might insist that such disagreement simply reveals that the thoughts of the philosopher under examination are fundamentally confused and unclear, and that they therefore ought to be rejected. A contrasting and more sensible view would be that any philosophical work worth discussing decades and centuries later has a scope and depth to it that allows for conflicting interpretations and that the continuing critical engagement with the tradition is part of what philosophy is all about. Should one be so unwise as to choose the first option, however, it should be obvious that one cannot then single out a few figures for condemnation, one should at the very least be consistent, and then reject the whole lot: Plato, Aristotle, Augustine, Aquinas, Descartes, Leibniz, Locke, Hume, Kant, Nietzsche, etc.
} 
description must take place from within some form of methodological reduction that shifts the focus of description to the transcendental, or at least quasi-transcendental, level" (Sparrow 2014, 14). According to Sparrow, however, the price for this methodologically unifying transcendental commitment is too high: It entails that phenomenology has to abandon and prohibit metaphysics. But if that is the case, phenomenology cannot offer or provide a defence of full blown metaphysical realism, or as Sparrow puts it: "when this book proclaims the end of phenomenology, it means that phenomenology as a method for realists has worn itself out" (Sparrow 2014, 13).

After having argued at length that the execution of the epoché and transcendental reduction prevents phenomenology from making any judgments regarding the existence of things, for which reason phenomenology has to remain metaphysically neutral or agnostic, Sparrow makes his final move and claims that phenomenology cannot remain neutral, but that it ultimately must align itself with a form of antirealism or idealism (Sparrow 2014, 26). It is not clear how Sparrow can reconcile the claim that phenomenology has no method, that it has a transcendental method that prohibits metaphysical commitments, and that its method commits it to idealism, but given his general interpretational tactics, it cannot wonder that he faults the phenomenologists (rather than his own interpretation) for the inconsistency (see Sparrow 2014, 31, 80).

Let me not spend more time on Sparrow's interpretation and accusations. His main conclusion and objection is that phenomenology cannot yield metaphysical realism. Despite its promise of returning us to the "things themselves" it keeps us chained to the phenomenal. To that extent, phenomenology remains committed to a form of Kantianism, rather than providing a real realist alternative (Sparrow 2014, 1). If we want to get out of "Kant's shadow" we shouldn't turn to phenomenology, but to speculative realism, since only "speculative realism returns us to the real without qualification and without twisting the meaning of realism" (Sparrow 2014, xii).

\section{Speculative realism}

What is speculative realism? It takes its name from a conference held at Goldsmiths College, University of London, in April 2007. The conference featured presentations by Ray Brassier, Iain Hamilton Grant, Graham Harman, and Quentin Meillassoux (Brassier et al. 2007). As quickly became apparent, these four protagonists diverged rather significantly when it came to their own positive proposals. Their philosophical progenitors included so diverse figures as Whitehead, Latour, Heidegger, Churchland, Metzinger, Sellars, Nietzsche, Levinas, Badiou and Schelling, but they were united by what they opposed. They all had one common enemy: Correlationism.

Correlationism is the view that subjectivity and objectivity cannot be understood or analyzed apart from one another because both are always already intertwined or internally related. It is the view that we only ever have access to the correlation between thinking (theory) and being (reality) and never to either in isolation from or independently of the other. On this view, thought cannot get outside itself in order to compare the world as it is 'in itself' with the world as it is 'for us'. Indeed, we can neither think nor grasp the 'in itself' in isolation from its relation to the subject, nor can we ever grasp a subject that would not always-already be related to an object. ${ }^{3}$

\footnotetext{
${ }^{3}$ Although Meillassoux is often credited with the coinage of the term $(2008,5)$, "correlationism" was in fact used and defined much earlier. Here is Beck in 1928: "'Korrelativismus' soll hier als Terminus dienen zur Bezeichnung eines von
} 
It was allegedly Kant who introduced this type of philosophy. ${ }^{4}$ Prior to Kant, one of the principal tasks of philosophy was to comprehend the universe, whereas since Kant, its primary focus and locus has been the correlationist circle. Rather than engaging in straightforward metaphysics, the effort has in turn been devoted to investigations of intentional correlations, language games, conceptual schemes, and discourses.

The speculative realists are unequivocal in their criticism of this development, which is described as the "Kantian catastrophe" (Meillassoux 2008: 124) that enduringly has "poisoned philosophy" (Badiou 2009, 535). Their hostility towards phenomenology is partially explained by the fact that it very much is a tradition "that seeps from the rot of Kant" (Bogost 2012, 4). That phenomenology is indeed a form of correlationism is easy to illustrate:

The first breakthrough of this universal a priori of correlation between experienced object and manners of givenness (which occurred during work on my Logical Investigations around 1898) affected me so deeply that my whole subsequent life-work has been dominated by the task of systematically elaborating on this a priori of correlation (Husserl 1970, 166).

The genuine transcendental epoché makes possible the "transcendental reduction" - the discovery and investigation of the transcendental correlation between world and worldconsciousness (Husserl 1970, 151).

[O]ne must not let oneself be deceived by speaking of the physical thing as transcending consciousness or as 'existing in itself.' [...] An object existing in itself is never one with which consciousness or the Ego pertaining to consciousness has nothing to do (Husserl 1982, 106).

World exists - that is, it is - only if Dasein exists, only if there is Dasein. Only if world is there, if Dasein exists as being-in-the-world, is there understanding of being, and only if this understanding exists are intraworldly beings unveiled as extant and handy. Worldunderstanding as Dasein-understanding is self understanding. Self and world belong together in the single entity, the Dasein. Self and world are not two beings, like subject and object, or like I and thou, but self and world are the basic determination of the Dasein itself in the unity of the structure of being-in-the-world (Heidegger 1982: 297).

\footnotetext{
Husserl und Dilthey erarbeiteten Standpunktes, der die alten Disjunktionen Idealismus oder Realismus, Subjektivismus oder Objektivismus, Immanenzphilosophie und Phänomenalismus oder Realphilosophie überwunden hat zugunsten der These: Weder existiert eine Welt an sich, unabhängig von einem Bewußtsein von ihr, noch existiert bloß ein Bewußtsein, resp. Bewußtseinssubjekt und nur als des Bewußtseins, resp. Subjekts bloßer Modus (Erlebnis, Funktion oder Inhalt) die Welt. Und: weder erkennen wir die Welt, wie sie an sich, d. i. unabhängig von unserem Bewußtsein ist, noch erkennen wir bloß eine Scheinwelt, jenseits derer die eigentliche, wahre Welt an sich existierte. Die korrelativistische Gegenthese lautet positiv: Bewußtsein und Welt, Subjekt und Objekt, Ich und Welt stehen selbst in einem derartigen korrelativen, d. i. sich gegenseitig bedingenden Seinszusammenhang, daß obige Disjunktionen überhaupt keinen Sinn haben" (Beck 1928, 611). I am indebted to Genki Uemura for this reference.

${ }^{4}$ The fact that Kant kept on to the idea of the thing-in-itself was of course an affront to the German Idealists, who saw it as an expression of Kant's inability to carry through his own revolutionary project. Whereas Kant would claim that things outside of the correlation are nothing to us, Hegel would downgrade the "nothing to us" to a "nothing at all" (Braver $2007,81)$. Whether Kant's view commits him to a two-world theory is debated, however. For a recent rejection of this idea, see Allais 2004.
} 
The world is inseparable from the subject, but from a subject who is nothing but a project of the world; and the subject is inseparable from the world, but from a world that it itself projects. The subject is being-in-the-world and the world remains 'subjective,' since its texture and its articulations are sketched out by the subject's movement of transcendence (Merleau-Ponty 2012: 454).

Speculative realist, by contrast, insist that the "world in itself - the world as it exists apart from us - cannot in any way be contained or constrained by the question of our access to it" (Shaviro 2011, 2 ). Their aim is to break out of the correlationist circle, and once more reach "the great outdoors, the absolute outside of pre-critical thinkers: that outside which was not relative to us [...] existing in itself regardless of whether we are thinking of it or not" (Meillassoux 2008, 7).

Kant warned us "never to venture with speculative reason beyond the boundaries of experience" (Kant 1998, B xxiv). The speculative realists by contrast urge us to do exactly that: "Pace Kant, we must think outside of our own thought; and we must positively conceive the existence of things outside our own conceptions of them" (Shaviro 2011: 2). Indeed, on Sparrow's view, only speculative realism offers "the kind of speculation required for grounding realism in philosophical argument" (Sparrow 2014, 22). Although Sparrow does not explain why only speculation should be able to ground realism philosophically, let us follow his suggestion and see where these speculations lead us.

According to Graham Harman, the only way to reverse Kant's human-world duopoly and the anthropocentric bias of phenomenology is by opting for equality. The human-world relation is just a special case of the relation between any two entities whatsoever, or as Harman and Bogost phrase it:

All relations in the cosmos, whether it be the perceptual clearing between humans and world, the corrosive effect of acid on lime stone, or a slap-fight between orangutans in Borneo, are on precisely the same philosophical footing (Harman 2005, 75).

[T] here is no reason to believe that the entanglement in which a noodle finds itself is any less complex than the human who shapes, boils, vends, consumes, or digests it (Bogost 2012, 30).

At first sight, the claim that causal relations between non-human objects are no different in kind from subject-object relations (Harman 2011, 198) seems rather familiar. It is strongly reminiscent of various reductionist attempts to naturalize intentionality, i.e. attempts to account for intentionality in terms of non-intentional mechanisms. But appearances are (in this case) misleading. When insisting on equality, the aim is not to reduce the mind (and its cognitive and affective relation to the world) to mindless mechanics. No, if anything the aim seems the reverse, namely to finally recognize that all objects, including fireplaces, lawnmowers or slices of rotting pork possess an inner infinity of their own (Morton 2012, 132). Indeed, as Harman insists, the real weakness of phenomenology has precisely been its failure to capture the "II' of sailboats and moons" $(2005,104)$. Phenomenology has been too restrictive, and has failed to recognize that it is entirely appropriate to ask "What's it like to be a computer, or a microprocessor, or a ribbon cable? [...] What do they experience? What's their proper phenomenology? In short, what is it like to be a thing?" (Bogost 2012, 9-10). 
Pan- (or as Harman prefers to label it) polypsychism emerges, on his view, "directly from the rejection of the Kantian Revolution" (Harman 2011: 170). One might wonder how direct and necessary that link is. On closer consideration, however, one might also wonder whether such a move really undermines correlationism, or whether it rather supports and expands it. Such worries also seem to have troubled Harman since he in other publications has argued that panpsychism and human exceptionalism share a common feature: the idea that the psyche is one of the key building blocks in the universe (Harman 2005: 220). This is the fundamental assumption that has to be rejected. There might indeed be a difference between humans and minerals, but there is also a difference between the hum of a refrigerator and a bucket of yellow paint, and ultimately we just have to face up to the fact that consciousness is simply one type of object among many others. There is no reason to prioritize it. If anything has to be prioritized, it is sincerity. As Harman writes, "[R]ocks and dust must be every bit as sincere as humans, parrots or killer whales" (Harman 2005: 220). Some readers will undoubtedly be puzzled by now. But there is more puzzlement in store for us. As Harman also declares, "philosophy's sole mission is weird realism. Philosophy must be realist because its mandate is to unlock the structure of the world itself; it must be weird because reality is weird" (Harman 2008: 334). Indeed, one reason to be dissatisfied with Husserl is that he is "neither weird, nor a realist, and even looks like the opposite: a "non-weird antirealist"' (Harman 2008: 348). ${ }^{5}$

Despite his criticism of correlationist subjectivism, Harman is no friend of naturalist objectivism. In fact, on his account, scientific naturalism is itself a form of correlationism. It is merely yet another attempt to squeeze and conform reality to our (current scientific) mindset: "The thing as portrayed by the natural sciences is the thing made dependent on our knowledge, and not the thing in its untamed, subterranean reality" (Harman 2011: 80). But if science doesn't reveal or disclose the mind-independent uncorrelated objects, how do we then gain access or knowledge about them? We do not. We can only know the appearance of the thing and never its true being. On Harman's account, the real objects, the things-in-themselves, forever remain inaccessible. As he remarks polemically against Heidegger: "To use a hammer and to stare at it explicitly are both distortions of the very reality of that hammer as it goes about just being itself, unleashed in the world like a wild animal" (Harman 2005: 74). Importantly, this inaccessibility of the in-itself is not due to some specific human cognitive flaw or incapacity, since Harman also holds the view that objects are hidden from and inaccessible to each other. The wind blowing on the banana, the hail hitting the tent, the rock colliding with the window, the flame consuming the cotton: In each case, the objects recede and withdraw from

\footnotetext{
${ }^{5}$ Some of Harman's ideas are reminiscent of ideas found elsewhere, namely in phenomenology. Consider, for instance, Merleau-Ponty's claim that idealism and constructivism deprive the world of its transcendence. Had the former positions been true, had the world really been a mere product of our constitution, the world would have appeared in full transparency, it would only have possessed the meaning we ascribe to it, and would have had no hidden aspects. In truth however, the world is an infinite source of richness, it is mystery and a gift (Merleau-Ponty 2012: 1xxv, lxxxv). Consider also Levinas' claim that object-intentionality cannot provide us with an encounter with true otherness. When I study or utilize objects, I am constantly transforming the foreign and different into the familiar and same, thereby making them lose their strangeness. This is also why, according to Levinas, Husserlian phenomenology cannot accommodate and do justice to the transcendence of the other. The other is exactly that which cannot be conceptualized or categorized. Any attempt to grasp or know the other necessarily domesticates and distorts what is ultimately an ineffable and untotalizable exteriority (Levinas 1972). It is debatable whether Merleau-Ponty's criticism of idealism is a criticism of Husserlian idealism, or whether it is rather targeting Kant and French neo-Kantians like Brunschvicg. It is also a matter of dispute whether Levinas' criticism of Husserl is justified (cf. Overgaard 2003). In either case, however, it is important to realize that the criticism in question is an internal criticism, it is a criticism preempted by and developed within phenomenology.
} 
each other (Harman 2005: 19). Everything is isolated from everything else; nothing is ever in direct contact with anything else. This principle holds not only on the inter-objective level, but even on the intra-objective level: An object also withdraws from and has no direct contact with its constituent parts (Harman 2005: 94, 172).

Harman criticizes phenomenology for its alleged anti-realism and argues that it chains us to the phenomenal. Whatever merit there is to this criticism, it certainly seems like a rather fitting description of his own position. Harman's fervent endorsement of realism goes hand in hand with a radical global scepticism that forever makes reality inaccessible to us. A fact that has not prevented him from making various claims about the structure and nature of this inaccessible realm.

Not all speculative realists share Harman's scepticism, however. Some of them has a far more positive view of science. In After Finitude, for instance, Meillassoux argues that phenomenology because of its commitment to correlationism is unable to accept the literal truth of scientific statements concerning events happening prior to the emergence of consciousness. When faced with a statement like "The accretion of the Earth happened 4.56 billion years ago", phenomenology is forced to adopt a two-layered approach. It has to insist on the difference between the immediate, realist, meaning of the statement, and a more profound, transcendental, interpretation of it. It can accept the truth of the statement, but only by adding the codicil that it is true "for us". Meillassoux finds this move unacceptable and claims that it is dangerously close to the position of creationists (Meillassoux 2008, 18, cf. Brassier 2007, 62). He insists that fidelity to science demands that we take scientific statements at face value and that we reject correlationism. No compromise is possible. Either scientific statements have a literal realist sense and only a realist sense or they have no sense at all (Meillassoux 2008: 17). ${ }^{6}$ To put it differently, science gives us access to a reality that cannot be contained in or captured by any correlationist framework. More specifically, Meillassoux endorses a kind of Cartesian rationalism and rehabilitates the distinction between primary and secondary qualities. The former are mathematically graspable features of the things-in-themselves. Mathematics is consequently able to describe a world where humanity is absent; it can describe the great outdoors; it can give us absolute knowledge from a view from nowhere (Meillassoux 2008: 26). In the course of his argumentation, Meillassoux also defends the view, however, that everything is without reason and therefore capable of becoming otherwise without reason. Meillassoux takes this ultimate absence of reason to be an absolute ontological property (2008: 53), and describes it as "an extreme form of chaos, a hyper-Chaos, for which nothing is or would seem to be, impossible, not even the unthinkable" (2008: 64). As he admits himself, it is quite a task to reconcile this view, which maintains that the laws of nature can change at any time for no reason whatsoever (2008: 83), with an attempt to secure the scientific discourse and the idea that mathematical science can describe the in-itself and permit knowledge of the ancestral (2008: 65).

\footnotetext{
${ }^{6}$ Despite being sympathetic to Meillassoux's criticism of correlationism, Brassier has argued that the former's focus on ancestrality and on arch-fossils (materials indicating the existence of events anterior to terrestrial life) is unfortunate. To "insist that it is only the ancestral dimension that transcends correlational constitution, is to imply that the emergence of consciousness marks some sort of fundamental ontological rupture, shattering the autonomy and consistency of reality, such that once consciousness has emerged on the scene, nothing can pursue an independent existence any more. The danger is that in privileging the arche-fossil as sole paradigm of a mind-independent reality, Meillassoux is ceding too much ground to the correlationism he wishes to destroy" (Brassier 2007, 60).
} 
An even more extreme form of anti-correlationist scientism can be found in the work of Brassier. On his account, the ultimate aim and true consummation of the Enlightenment project is a radical demolishment of the manifest image (Brassier 2007, 26). Brassier consequently lauds Churchland's eliminativist criticism of Folk Psychology, and sees speculative realism as a metaphysical radicalization of eliminativism (Brassier 2007, 31); a radicalization that ultimately leads to nihilism:

Nihilism is the unavoidable corollary of the realist conviction that there is a mindindependent reality, which, despite the presumptions of human narcissism, is indifferent to our existence and oblivious to the 'values' and 'meanings' which we would drape over it in order to make it more hospitable (Brassier 2007, xi).

The world as it is in itself is inherently devoid of intelligibility and meaning. To realize this, to realize the senselessness and purposelessness of everything is a mark of intellectual maturity (Brassier 2007, xi, 238). This realization has also implications for our assessment of the value of philosophical thinking. As Brassier concludes Nihil Unbound: “[P]hilosophy is neither a medium of affirmation nor a source of justification, but rather the organon of extinction" (Brassier 2007: 239). One inevitable wonders how such a verdict affects the assessment of Brassier's own philosophy, just as one might wonder whether one can consistently celebrate the virtue of intellectual maturity at the same time as one denies the reality of sense, meaning, intelligibility and purpose.

\section{Forms of realism}

How fatal is this criticism of phenomenology? How much of a threat to phenomenology does it constitute? Let us for a moment return to Harman, and consider another statement of his:

We have seen that one of the worst effects of phenomenology was to cement the notion that the dispute between realism and anti-realism is a 'pseudo-problem.' Since intentionality is always directed toward something outside itself, perceiving or hating some object, phenomenology supposedly gives us all the realism we will ever need, and without falling into the 'naïve' realism that posits entities beyond all possible perception. The problem is that the objects of intentionality are by no means real, as proven by the fact that we hate, love, or fear many things that turn out not to exist in the least. By confining itself to sensual objects and leaving no room for real ones, phenomenology is idealist to the core, and cannot get away with dismissing as a 'pseudo-problem' a difficulty that happens to threaten its own views about the world (Harman 2011, 197).

This criticism is unconvincing. It is an obvious non sequitur to argue that since some objects of intentionality are non-existing, all objects of intentionality are non-existing (or unreal). Furthermore, already in Logische Untersuchungen Husserl rejected any facile distinction between intentional objects (which Harman terms sensual objects) and real objects, and argued that 
the intentional object of a presentation is the same as its actual object, and on occasion as its external object, and that it is absurd to distinguish between them. The transcendent object would not be the object of this presentation, if it was not its intentional object. This is plainly a merely analytic proposition. The object of the presentation, of the 'intention', is and means what is presented, the intentional object (Husserl 2001, 127).

This is not to say that all intentional objects are real, but only that if the intended object really exists, then it is this real object, and no other, which is our intentional object. In other words, for Husserl the distinction to keep unto is not the one between the intentional object and the real object, but the one between the merely intentional object, and the real and intentional object:

'The object is merely intentional' does not, of course, mean that it exists, but only in an intention, of which it is a real (reelles) part, or that some shadow of it exists. It means rather that the intention, the reference to an object so qualified, exists, but not that the object does. If the intentional object exists, the intention, the reference, does not exist alone, but the thing referred to exists also (Husserl 2001, 127).

What about Harman's claim that the recurrent attempt by phenomenology to dismiss the dispute between realism and anti-realism as a pseudo-problem is disingenuous, since phenomenology is idealist to its core? This claim is not merely quite controversial; it is also historically incorrect. Whereas it is true that some phenomenologists have suggested that one should stay clear of the realism/anti-realism (idealism) controversy, it is certainly not a position shared by all. Husserl often expressed his commitment to a form of idealism - though the precise nature and character of this idealism remains contested. Whether it amounts to a metaphysical idealism or whether it is compatible with a form of realism is debated in the scholarly literature (Zahavi 2008, 2010b). More importantly, however, many early phenomenologists (including members of the Munich and Göttingen circles of phenomenology, i.e. figures like Reinach, Pfänder, Scheler, Stein, Geiger, Hildebrand and Ingarden) were committed realists who were quite disappointed by what they saw as Husserl's turn towards transcendental idealism. They considered this turn a betrayal of the realist thrust of phenomenology and very much saw themselves as defending realism (Smith 1997). Finally, to mention one further example, Heidegger is often portrayed by the speculative realists as an even more fierce idealist and correlationist than Husserl (cf. Sparrow 2014, 36). This characterization, however, is by no means univocally accepted by Heidegger scholars. Many see him as a realist (Dreyfus \& Spinosa 1999, Carman 2003). There are even those who interpret him as a scientific realist (Glazebrook 2001). Recently, even Husserl has been interpreted along similar lines. In his 2014 book Nature's Suit: Husserl's Phenomenological Philosophy of the Physical Sciences, Hardy defends the view that Husserl's transcendental idealism and his claims concerning the dependence of physical objects on consciousness must be understood within a justification-theoretic context and is wholly compatible with scientific realism (Hardy 2014, 201). 
Matters are in short far more complex than suggested by the speculative critics, and ultimately one has to wonder whether they are reliable and knowledgeable interpreters of the tradition they are criticizing. ${ }^{7}$

But back to the main issue, the criticism of correlationism and the articulation and defense of robust realism. The speculative realists are certainly right in their assessment of how widespread correlationism is. It has indeed been "the reigning doxa of post-metaphysical philosophy" (Brassier 2007, 50), and although Husserl in Krisis claims to have been the first to investigate the correlation philosophically (Husserl 1970, 165), correlationism cannot be dismissed as a Husserlian idiosyncrasy. To illustrate its presence also in recent analytic philosophy, consider the case of Putnam. ${ }^{8}$

Putnam is known as a(n occasional) critic of metaphysical realism and has at one point conceived of his own alternative - which he in turn labeled "internal realism," "natural realism," "pragmatic realism" or "commonsense realism" - as an attempt to find a third way beyond classical realism and subjective idealism, and between "reactionary metaphysics and irresponsible relativism" (Putnam 1999, 5).

According to metaphysical realism, there is a clear distinction to be drawn between the properties things have "in themselves" and the properties that are "projected by us" (Putnam 1990, 13). One can illustrate this way of thinking by way of the following metaphor: Whereas reality as it is in itself, independently of us, can be compared to a dough, our conceptual contribution can be compared to the shape of a cookie cutter. The world itself is fixed and stable, but we can conceive of it in different ways. But as Putnam insists, this view suffers from an intolerable naiveté:

What the Cookie Cutter Metaphor tries to preserve is the naive idea that at least one Category - the ancient category of Object or Substance - has an absolute interpretation. The alternative to this idea is not the view that, in some inconceivable way, it's all just language. We can and should insist that some facts are there to be discovered and not legislated by us. But this is something to be said when one has adopted a way of speaking, a language, a 'conceptual scheme.' To talk of 'facts' without specifying the language to be used is to talk of nothing; the word 'fact' no more has its use fixed by Reality Itself than does the word 'exist' or the word 'object' (Putnam 1987, 36).

Thus, according to Putnam, it is an illusion to think that the notions of "object" or "reality" or "world" have any sense outside of and independently of our conceptual schemes (Putnam 1992, 120). Putnam is not denying that there are "external facts"; he even thinks that we can say what they are. But as he writes, "what we cannot say-because it makes no sense-is what the facts are independent of all conceptual choices" (Putnam 1987, 33). This is not to say that our conceptual schemes create the world, but they do not just mirror it either (Putnam 1978, 1). Ultimately, what we call "reality" is so deeply suffused with mind- and language-dependent structures that it is altogether impossible to make a neat distinction between those parts of our beliefs that reflect the world "in itself" and those parts

\footnotetext{
${ }^{7}$ For an in-depth engagement with and criticism of Harman's Heidegger-interpretation, see Wolfendale 2014. For a more well-informed, though in my view still too uncharitable, critical reading of Husserl, see Sebold 2014.

${ }^{8}$ For a more extensive discussion of the relation between Putnam and Husserl, cf. Zahavi 2004b.
} 
of our beliefs that simply expresses "our conceptual contribution." The very idea that our cognition should be nothing but a re-presentation of something mind-independent consequently has to be abandoned (Putnam 1990, 28):

Given this outlook, it cannot surprise that Putnam is skeptical when metaphysical realists insist that there is a gap between epistemological and ontological issues, and when they deny that epistemological distinctions have any ontological implications. As Putnam retorts, the "epistemological" and the "ontological" are intimately related, and any serious philosophical work must respect their interconnection (Putnam 1988, 120).

In his discussion of these issues, Putnam sometimes accuses scientific realists of not being sufficiently realist. Occasionally the claim is being made that science is the sole legitimate source of empirical knowledge. Thereby a certain theoretical outlook is made the measure of what counts as real, and the existence of everyday objects and events such as tables, marriages, economic crises, and civil wars are denied, with the argument that none of them figures in the world as described by physics (Putnam 1987, 12). Although scientific realism was once heralded as a strong antidote against idealism and scepticism, Putnam consequently argues that it has joined forces with what it was supposed to combat.

When Putnam insists that the metaphysical realists do not take realism sufficiently seriously, and when he argues that it is the philosophers traditionally accused of idealism, namely the Kantians, the Pragmatists, and the Phenomenologists, who actually respect and honor our natural realism (Putnam 1987, 12), he is following in the footsteps of Husserl. As Husserl declared in a famous letter to Émile Baudin: "No ordinary 'realist' has ever been so realistic and so concrete as I, the phenomenological 'idealist"' (Husserl 1994, 16).

Although the main speculative criticism of phenomenology concerns its alleged failure to be sufficiently realist, although Sparrow insists that speculative realism "returns us to the real without qualification and without twisting the meaning of realism" (Sparrow 2014, xii), it should by now be obvious that the realism on offer is of a rather peculiar kind. Harman defends a radical skepticism that denies us any glimpse of reality (while making various claims about the character of this ungraspable reality-in-itself), and whereas Meillassoux seeks to reconcile an old-style rationalism according to which only that which is amenable to mathematization counts as real with the idea that chaos is the primary absolute, Brassier opts for a nihilist eliminativism. How robustly realist are these divergent positions? If realism is about affirming the reality of everyday objects, the speculative realists fail miserably.

Husserl was in part led by similar considerations as Putnam. It was in order to ward off skepticism, it was in order to save the objectivity of the world that we know, that Husserl embraced transcendental idealism and insisted that reality involves a necessary intertwining of subject and object. Thus not unlike Kant, Husserl did not merely think that transcendental idealism and empirical realism are compatible; he thought that the latter required the former. By developing a sophisticated non-representationalist theory of intentionality, Husserl sought to rule out the possibility of a gap between the world that we investigate and the real world, thereby allowing global scepticism no purchase. In defending such a view, it is again important to realize that Husserl isn't a lone and late excrescence of German Idealism. There are striking parallels to views also found in analytic philosophy. As Davidson declares in "The structure and content of truth", realism - understood as 
the position that truth is "radically non-epistemic" and that all our best researched and established beliefs and theories may be false - is a view he considers incomprehensible (Davidson 1990, 308309). As he would later write in Subjective, Intersubjective, Objective: "A community of minds is the basis of knowledge; it provides the measure of all things. It makes no sense to question the adequacy of this measure, or to seek a more ultimate standard" (Davidson 2001, 218). ${ }^{9}$

It might be tempting to accuse the correlationists of committing hubris, by defining reality in terms of what we can have access to. But as Braver has pointed out, one might also reverse this particular criticism (Braver 2012, 261-262). Not only do the speculative realists make claims about that which transcends us, but they (at least some of them) are also the ones who aspire to absolute knowledge. It is no coincidence that Meillassoux's book is called After Finitude. By contrast, correlationism might be a way of acknowledging the finite and perspectival character of our knowledge.

\section{The end of speculative realism}

Given the hostility towards and proclaimed showdown with phenomenology, one might have expected more in terms of scholarly engagement with the tradition. As already mentioned, there are serious problems with the critical interpretation being offered and it falls short of the best work done by scholars of Husserl, Heidegger, Merleau-Ponty etc. One of the utterly puzzling features of the criticism is the following. The main point of contention is the alleged idealist or anti-realist orientation of phenomenology. Because of this metaphysical commitment, phenomenology has come to an end. But the fallacy of this argument should be obvious. Even if some of the phenomenologists did indeed contribute to the realism-idealism debate, even if some of their analyses, in particular those pertaining to the very status of the phenomenon or to the scope of transcendental phenomenology, bear directly on this issue, it is certainly not as if phenomenologists were exclusively concerned with this issue. What about their investigations of intentionality, experience, emotions, self-consciousness, perception, imagination, social cognition, action, embodiment, truth, temporality, ethics, community, historicity, etc.? What about the fruitful interaction that is currently taken place between phenomenology and the (cognitive) sciences? What about the influence the phenomenological analyses have had on such disciplines as psychiatry, architecture, education, sports science, psychology, nursing, comparative literature, anthropology, sociology etc? To what extent are these analyses or contributions dependent upon phenomenology's transcendental commitment? To what extent are they undermined by speculative realism's attack on correlationism? To what extent is speculative realism in a position to offer its own more convincing analyses?

But - the critics might retort - even if speculative realism might lack the ability to do the latter, you are just sidetracking the issue. You are not responding to the ancestrality objection. Is correlationism really incompatible with the findings of science? Does an endorsement of the former make certain interpretations of scientific findings nonsensical? And if yes, is that not a reductio ad absurdum of correlationism? This would undoubtedly be the view of some scientists. As Hawking and Mlodinow put it in their book The Grand Design: New answers to the ultimate questions of life:

\footnotetext{
${ }^{9}$ For more on the relation between Davidson and Husserl, cf. Zahavi and Satne 2016.
} 
"Philosophy is dead" (Hawking and Mlodinow 2010: 5). I doubt many philosophers would endorse this verdict, but ultimately we need to ask whether science ought to be the final arbiter of deep philosophical questions. ${ }^{10}$ Is it appropriate to dismiss Kant's Kritik der reinen Vernunft (or Husserl's Ideen I) by appealing to the findings of astrophysics and evolutionary history (Brassier 2001: 28), or does such a "refutation" merely testify to a conflation of levels and categories? Although I veer towards the latter view, my aim is not to settle this issue here. My point is rather that regardless of which choice one makes, it will leave the speculative realists in an uncomfortable bind. If they simply defer to the authority of science, their criticism of phenomenology (and any other kind of correlationism) is not only bereft of philosophical import, it also lacks novelty. If they do not take that route, they lose one of their supposedly weightiest arguments, and will then have to buttress their criticism with proper philosophical arguments, for instance arguments taken from philosophy of science. But as Wiltsche has recently pointed out in a critical discussion of Meillassoux' work, the latter's treatment of and engagement with philosophy of science is astonishingly sparse (Wiltsche under review). In After Finitude, Meillassoux seems to take it for granted that scientific realism is the only available option. That, however, is hardly correct (for an informative overview cf. Chakravartty 2011). Furthermore, most standard textbooks in philosophy of science contain more arguments forand against - scientific realism than After Finitude (cf. Sankey 2008).

To put it differently, speculative realism's most substantial challenge to phenomenology is an old hat, and can be found in more potent form in analytic philosophy. Russell held the view that philosophers should strive towards becoming undistorting mirrors of the world $(1959,213)$, and claimed that results from astronomy and geology could refute Kant and Hegel by showing that the mind is of a recent date and that the processes of stellar evolution proceeded according to laws in which mind plays no part (Russell 1959, 16). If tempted by eliminativism, one can simply read the Churchlands, Metzinger, or Alex Rosenberg. It is harder to find an analytic counterpart to Harman's weird realism, but that is less surprising, and might also - depending on one's philosophical inclinations - be a good thing.

Let me try to take stock. The allegedly devastating criticism that speculative realism directs at phenomenology is flawed in various ways.

- It is too superficial: It misinterprets the classical texts and fails to engage sufficiently with relevant scholarship in the area

- It is too simplistic: Its misses out on important differences internal to phenomenology, such as the difference between early realist phenomenology and the transcendental idealism of Husserl, and claims to be able to assess the value and significance of phenomenological analyses tout court by criticizing what phenomenology has to say, or not to say, on the topic of metaphysics.

\footnotetext{
${ }^{10}$ In 1922, Moritz Schlick gave a talk where he argued that the general theory of relativity had disconfirmed transcendental philosophy and vindicated empiricist philosophy. This view has found much resonance, but as Ryckman observes in The Reign of Relativity: Philosophy in Physics 1915-1925, it happens to be quite incorrect. The outstanding mathematician Hermann Weyl, who was one of Einstein's colleagues in Zürich, and who contributed decisively to the interpretation and further development of both the general theory of relativity and the field of quantum mechanics, did not only draw quite extensively on Husserl's criticism of naturalism, but was also deeply influenced by Husserl's transcendental idealism (Ryckman 2005, 6, 110). Another distinguished physicist heavily influenced by Husserl was the quantum theorist Fritz London (cf. French 2002). Ultimately, one might wonder whether the decisive advances in theoretical physics at the beginning of the $20^{\text {th }}$ Century really leave our standard conception of subjectivity, objectivity and knowledge untouched.
} 
- It lacks novelty: The central objections have already previously been raised by (some) phenomenologists, analytic philosophers, and empirical scientists.

My focus has primarily been on the negative or critical contribution of speculative realism. Let me conclude with a few remarks concerning its positive contribution, with the obvious proviso that a definitive verdict would have to await (somebody else's) more exhaustive and thorough treatment and analysis:

- Its realist credentials are somewhat questionable, ranging from Harman's scepticism (with its paradoxical revival of something akin to Kant's noumenal realm) to Brassier's radical nihilism. It is an open question whether any of these positions are coherent.

- It is epistemologically underdetermined. Even when rejecting Putnam's (and the phenomenologists') claim that the ontological and the epistemological are deeply interconnected, many scientific realists would consider it of paramount importance to explain how human cognition can give rise to genuine knowledge of a mind-independent reality: How is knowledge possible? The phenomenologists likewise were led to their views regarding the status of reality through a focused exploration and analysis of intentionality. The speculative realists, by contrast, do not really offer much in terms of a theory of knowledge that could justify their metaphysical claims.

- Given the significant divergence between the positive views of Harman, Meillassoux and Brassier, one might finally wonder whether it at all makes sense to employ the collective label speculative realism. Sparrow obviously thinks so, although he does admit that the defenders of speculative realism do not actually share a critical method (Sparrow 2014, 19). "What then legitimates its speculative claims?" (Sparrow 2014, 19). The answer given by Sparrow is as brief as it is unsatisfactory. He writes that the speculative realists share "a set of commitments", including a "commitment to speculation" (Sparrow 2014, 19). But this merely restates the problem. What is the justification for the various (outlandish) claims being made? How should we distinguish speculation from free phantasy? A question that is particularly pressing when reading Harman. As Sparrow continues, to different degrees the speculative realists are committed to "a blending of fiction and fact", they have "a taste for the weird, the strange, the uncanny" (Sparrow 2014, 20), and their aim "is to clear the ground for new advances in the thinking of reality. This is, after all, the end of philosophy" (Sparrow 2014, 20). Perhaps speculative realism does indeed constitute the end of philosophy, or perhaps it has merely reached its own dead-end. If so, Sparrow's unfounded verdict on phenomenology would turn out to be an impressively accurate assessment of speculative realism: It never really got started and it is not clear that it ever was anything at all. This also seems to be a conclusion eventually reached by Brassier:

The 'speculative realist movement' exists only in the imaginations of a group of bloggers promoting an agenda for which I have no sympathy whatsoever: actor-network theory spiced with pan-psychist metaphysics and morsels of process philosophy. I don't believe the Internet is an appropriate medium for serious philosophical debate; nor do I believe it is acceptable to try to concoct a philosophical movement online by using blogs to exploit the misguided enthusiasm of impressionable graduate students. I agree with Deleuze's remark that ultimately the most basic task of philosophy is to impede 
stupidity, so I see little philosophical merit in a 'movement' whose most signal achievement thus far is to have generated an online orgy of stupidity (Brassier \& Rychter 2011). ${ }^{11}$

As for phenomenology, I think it currently finds itself at a crossroad. It continues to remain a source of inspiration for other disciplines, and at least certain of its ideas have also been taken up by analytic philosophy and cognitive science. At the same time, phenomenology remains under attack from a variety of different positions, including hard-nosed naturalism and neurocentrism, and after the death of Henry, Levinas, and Derrida it is not clear who, if any, their natural successors are. It is not easy to identify new thinkers who in equal measures are innovating phenomenology. As shown by The Oxford Handbook of Contemporary Phenomenology (Zahavi 2012b), what we rather find is a lot of work being done in two directions: inward (and backward) and outward (and forward). On the one hand, we find a continuing engagement and conversation with the founding fathers (and mothers). The philosophical resources and insights to be found in Husserl's, Heidegger's and Merleau-Ponty's work are evidently not yet exhausted. On the other hand, an increasing amount of dialogue is taking place between phenomenology and other philosophical tradition and empirical disciplines.

It is hard to predict how many self-avowed phenomenologists there will be 100 years from now. But I am quite confident that the basic insights found in phenomenology will continue to appeal to and attract and inspire gifted thinkers. In fact, if there is any truth to phenomenology, it should be able to renew itself, and continue to flourish in new forms and perhaps also under new names.

\section{REFERENCES}

Allais, L. (2004). Kant's One World: Interpreting “Transcendental Idealism.” British Journal for the History of Philosophy, 12(4), 655-684.

Badiou, A. (2009). Logics of Worlds: Being and Event 2. London: Continuum.

Beck, M. (1928). Die neue Problemlage der Erkenntnistheorie. Deutsche Vierteljahrsschrift für Literaturwissenschaft und Geistesgeschichte 6, 611-639.

Bogost, I. (2012). Alien Phenomenology, or What it's Like to be a Thing. Minneapolis: University of Minnesota Press.

Brassier, Ray (2001). Alien theory: the decline of materialism in the name of matter. PhD thesis, University of Warwick.

Brassier, R. (2007). Nihil Unbound: Enlightenment and Extinction. New York: Palgrave Macmillan.

\footnotetext{
${ }^{11}$ Brassier's assessment points to an important aspect of speculative realism that I have not been able to address: the specific sociological context of its emergence and diffusion. What institutional establishment was it a reaction against, and why did it gain popularity at the time and in the way it did?
} 
Brassier, R., \& Rychter, M. (2011). I Am a Nihilist Because I Still Believe in Truth. Kronos. Retrieved October 5, 2015 from http://www.kronos.org.pl/index.php?23151,896

Brassier, R., Grant, I. H., Harman, G., \& Meillassoux, Q. (2007). Speculative Realism. Collapse III, 306-449.

Braver, L. (2007). A Thing of This World: A History of Continental Anti-realism. Evanston: Northwestern University Press.

Braver, L. (2012). A Brief History of Continental Realism. Continental Philosophy Review, 45(2), 261-289.

Carman, T. (2003). Heidegger's Analytic: Interpretation, Discourse, and Authenticity in Being and Time. Cambridge: Cambridge University Press.

Chakravartty, A. (2011). Scientific Realism. In E. N. Zalta (ed.), The Stanford Encyclopedia of Philosophy, http://plato.stanford.edu/entries/scientific-realism/

Davidson, D. (1990). The structure and content of truth. Journal of Philosophy, 87/6, 279-328.

Davidson, D. (2001). Subjective, intersubjective, objective. Oxford: Oxford University Press.

Dreyfus, H. L., \& Spinosa, C. (1999). Coping with Things-in-themselves: A Practice-Based Phenomenological Argument for Realism. Inquiry, 42(1), 49-78.

French, S. (2002). A phenomenological solution to the measurement problem? Husserl and the foundations of quantum mechanics. Studies in History and Philosophy of Science Part B 33 (3): $467-$ 491.

Glazebrook, T. (2001). Heidegger and scientific realism. Continental Philosophy Review, 34(4), 361401.

Hardy, L. (2014). Nature's Suit: Husserl's Phenomenological Philosophy of the Physical Sciences. Athens, OH: Ohio University Press.

Harman, G. (2005). Guerrilla Metaphysics: Phenomenology and the Carpentry of Things. Chicago: Open Court.

Harman, G. (2008). On the Horror of Phenomenology: Lovecraft and Husserl. Collapse IV. 333-364.

Harman, G. (2011). The Quadruple Object. Alresford: Zero Books. 
Hawking, S., Mlodinow, L. (2010). The Grand Design. New York: Bantam Books.

Heidegger, M. (1982). The Basic Problems of Phenomenology. Bloomington: Indiana University Press.

Husserl, E. (1970). The Crisis of European Sciences and Transcendental Phenomenology. Evanston: Northwestern University Press.

Husserl, E. (1982). Ideas pertaining to a pure Phenomenology and to a Phenomenological Philosophy. First Book: General Introduction to a Pure Phenomenology. The Hague: Martinus Nijhoff.

Husserl, E. (1994). Briefwechsel—Wissenschaftlerkorrespondenz. Husserliana Dokumente III/7. Ed. K. Schuhmann. Dordrecht: Kluwer.

Husserl, E. (2001). Logical Investigations II. London: Routledge.

Kant, I. (1998). Critique of Pure Reason. Cambridge: Cambridge University Press.

Levinas, E. (1972). Totality and Infinity: An Essay on Exteriority. Pittsburgh: Duquesne University Press.

Meillassoux, Q. (2008). After Finitude. An Essay on the Necessity of Contingency. London: Continuum.

Merleau-Ponty, M. (2012). Phenomenology of Perception. London: Routledge.

Morton, T. (2012). Art in the age of asymmetry: Hegel, objects, aesthetics. Evental Aesthetics 1/1, 121-142.

Overgaard, S. (2003). On Levinas' Critique of Husserl. In D. Zahavi, S. Heinämaa, H. Ruin (eds.): Metaphysics, Facticity, Interpretation (pp. 115-138). Dordrecht: Kluwer.

Putnam, H. (1978). Meaning and the Moral Sciences. London: Routledge \& Kegan Paul.

Putnam, H. (1987). The Many Faces of Realism. LaSalle, Illinois: Open Court.

Putnam, H. (1988). Representation and Reality. Cambridge, MA: MIT Press.

Putnam, H. (1990). Realism with a Human Face. Cambridge, MA: Harvard University Press. 
Putnam, H. (1992). Renewing Philosophy. Cambridge, MA: Harvard University Press.

Putnam, H. (1999). The Threefold Cord. Mind, Body, and World. New York: Columbia University Press.

Petitot, J. et al. (eds.) (1999). Naturalizing phenomenology: Issues in contemporary phenomenology and cognitive science. Stanford: Stanford University Press.

Rockmore, T. (2011). Kant and Phenomenology. Chicago: University of Chicago Press.

Russell, B. (1959). My Philosophical Development. Simon and Schuster.

Ryckman, T. (2005). The Reign of Relativity: Philosophy in Physics, 1915-1925. Oxford: Oxford University Press.

Sankey, H. (2008). Scientific Realism and the Rationality of Science. Aldershot: Ashgate.

Sebold, R. (2014). Continental Anti-Realism: A Critique. London: Rowman \& Littlefield International.

Shaviro, S. (2011). Panpsychism and/or eliminativism. Retrieved October 5, 2015 from http://www.shaviro.com/Blog/?p=1012

Smith, B. (1997). Realistic Phenomenology. In Lester Embree (ed.), Encyclopedia of Phenomenology (pp.586-590). Dordrecht: Kluwer.

Sparrow, T. (2014). The End of Phenomenology: Metaphysics and the New Realism. Edinburgh: Edinburgh University Press.

Varela, F. J. (1996). Neurophenomenology: A Methodological Remedy for the Hard Problem. Journal of Consciousness Studies, 3(4), 330-349.

Wiltsche, H. (under review): Science, Realism and Correlationism. A Phenomenological Critique of Meillassoux’ Argument from Ancestrality

Wolfendale, P. (2014). Object-Oriented Philosophy: The Noumenon's New Clothes. Urbanomic.

Zahavi, D. (1996). Husserl und die transzendentale Intersubjektivität. Eine Antwort auf die sprachpragmatische Kritik. Phaenomenologica 135. Dordrecht: Kluwer.

Zahavi, D. (2003). Husserl's Phenomenology. Stanford: Stanford University Press. 
Zahavi, D. (2004a). Phenomenology and the project of naturalization. Phenomenology and the Cognitive Sciences 3/4, 331-347.

Zahavi, D. (2004b). Natural Realism, Anti-Reductionism, and Intentionality. The 'Phenomenology' of Hilary Putnam. In D. Carr and C.-F. Cheung (eds.): Time, Space, and Culture (pp. 235-251). Dordrecht: Springer.

Zahavi, D. (2007). Phänomenologie für Einsteiger. München: Wilhelm Fink Verlag.

Zahavi, D. (2008). Phenomenology. In Moran, D. (ed.): Routledge Companion to Twentieth-Century Philosophy (pp. 661-692). London: Routledge.

Zahavi, D. (2010a). Naturalized Phenomenology. In S. Gallagher \& D. Schmicking (eds.): Handbook of Phenomenology and Cognitive Science (pp. 2-19). Dordrecht: Springer.

Zahavi, D. (2010b). Husserl and the 'absolute'. In C. Ierna, H. Jacobs, F. Mattens (eds.): Philosophy, Phenomenology, Sciences: Essays in Commemoration of Husserl (pp.71-92). Phaenomenologica Vol. 200. Dordrecht: Springer.

Zahavi, D. (2012a). Noesis and noema. The Times Literary Supplement, June 29, 28.

Zahavi, D. (ed.) (2012b). The Oxford Handbook of Contemporary Phenomenology. Oxford: Oxford University Press.

Zahavi, D. (2013). Naturalized Phenomenology: A Desideratum or a Category Mistake? Royal Institute of Philosophy Supplement 72, 23-42.

Zahavi, D. (2015). Phenomenology of reflection. In A. Staiti (ed.): Commentary on Husserl's Ideas I (pp. 177-193). Berlin: De Gruyter.

Zahavi, D., Satne, G. (2016). "Varieties of shared intentionality: Tomasello and classical phenomenology." In J. Bell, A. Cutrofello \& P. Livingston (eds.): Beyond the Analytic-Continental Divide: Pluralist Philosophy in the Twenty-First Century (pp. 305-325). London: Routledge. 